\title{
Inventory, colony fluctuation, and wasp nesting social habits in IFSULDEMINAS - Machado Campus
}

Elenice Aparecida Fortes ${ }^{1}$

Alice dos Reis Fortes ${ }^{2}$

Letícia Cruz de Almeida ${ }^{3}$

Lêda Gonçalves Fernandes 4

\section{Abstract}

Social wasps offer important ecosystem resources as biological control and pollination. Many species are synanthropic, however, there are still few studies of these insects in anthropized environments. The objective of this study was to verify the richness, colony fluctuation, and preferential substrates for social wasp nesting at IFSULDEMINAS Campus Machado. Four censuses/inventories were carried out from November 2015 to June 2016, and the active collection method with an entomological net was used for wasp collection. The specimens found were assembled, identified, and deposited in the collection of the entomology laboratory of the institution. In total, 20 species of social wasps were registered, from which the genera Polybia, Polistes, and Mischocyttarus showed a greater richness of species. The number of colonies increased from November to March, decreasing in June. Mischocyttarus cassununga R. von Ihering (1903) had more abundance of colonies in all months evaluated. Broadly, the genera Mischocyttarus and Polistes presented nesting preference for the building substrate, while the genus Polybia presented preference for the vegetation substrate. Machado Campus has a diversity of environments that contributes to the establishment of social wasp colonies. Therefore, it is essential to disseminate this information and environmental education actions to the community to demonstrate the importance of these insects for the ecosystem and the need for environmental conservation to guarantee their ecosystem services.

Keywords: Entomology. Hymenoptera Vespidae. Mischocyttarus. Synanthropism.

\section{Introduction}

Social wasps, popularly known as "marimbondos" or "cabas," are recognized mainly by the presence of their colony, called "caixa" or "enxu," and by their painful stings (PREZOTO et al., 2007). Such insects belong to the order Hymenoptera, superfamily Vespoidea, family Vespidae and subfamily Polistinae. The Polistinae are cosmopolitan eusocial insects, however, the greatest diversity is found in tropical regions, especially in the neotropical region. This subfamily has 26 genera and 974 species. In Brazil it is represented by 22 genera and more than 300 species, 104 of which are endemic, thus characterizing one of the richest faunas of the subfamily Polistinae in the world

1 Instituto Federal de Educação Ciência e Tecnologia do Sul de Minas Gerais (IFSULDEMINAS) - Campus Machado. Discente do curso de Licenciatura em Ciências Biológicas. forteselenice@gmail.com. Rodovia Machado, Paraguaçu, km 3, Bairro Santo Antônio, Machado/MG, 37.750-000. 
(CARPENTER; MARQUES, 2001; PREZOTO; CLEMENTE, 2010; RESENDE et al., 2016). In the state of Minas Gerais, southeastern Brazil, 101 species and 17 genera were registered (SOUZA; FERREIRO; ALBUQUERQUE, 2015).

As eusocial insects, wasps have overlapping generations in the same colony, cooperative care for offspring, and division of tasks. They have two strategies for the foundation of a new nest: independent foundation and swarming foundation. In the first strategy, one or more females start the new colony, which is characterized by its reduced size and few cells. On the other hand, in the swarming foundation, a group of workers and queens start the new colony. Usually, this foundation occurs by the abandonment or division of the old colony, and it is characterized, in turn, by the largest size and largest population (RESENDE et al., 2016).

The wasps have a high degree of synthropism (PREZOTO, 1999), as they have opportunistic species, being able to modify their foraging behavior to take advantage of new and different sources of food resources (RESENDE et al., 2016). However, according to Oliveira, Souza, Pires (2017), and Torres et al. (2014), this association with urban environments may be related to the destruction of their natural habitats.

The selection of the nesting site, the orientation and architecture of the colonies are important mechanisms to regulate the microclimate within them and to ensure their success (ROCHA, 2011). In anthropic environments, wasps build their colonies on several substrates, some are more selective, others more generalist (OLIVEIRA; SOUZA; PIRES, 2017); and those that use only human constructions as substrate are more eusinanthropic (LIMA; LIMA; PREZOTO, 2000). In urban environments, the duration of a colony tends to be longer due to benefits such as more protection against weathering, reduced competition, and predation. However, this longevity is directly conditioned to human action (PREZOTO et al., 2007).

Due to their behavior and number of individuals, social wasps have a huge impact on other organisms (RICHTER, 2000), because, as the large predators they are, they guarantee the trophic balance of ecosystems. They are also pollinators of some species and bioindicators of environmental quality (RESENDE et al., 2016; SOMAVILLA; KÖHLER, 2012). They have a foraging habit, that is, they search for resources such as water, food, and materials such as fibers and clay to build their colonies (RESENDE et al., 2016). In adulthood, they feed on carbohydrates found in flowers and fruits and to feed their larvae they hunt prey (CASTRO; GUIMARÃES; PREZOTO, 2011). Water is a resource employed for cooling the colony, being of paramount importance on hotter days (ELISEl et al., 2010).

When searching for pollen, wasps are part of the community of floral visitors, and a portion represents effective pollinators (CLEMENTE et al. , 2017; SOMAVILLA; KÖHLER, 2012). Thus, several studies seek to characterize which wasp species are the most frequent floral visitors and associate them as effective pollinators. Sühs et al. (2009) collected the Polistes simillimus Saussure (1853), Polybia sericea Olivier (1791), and Polybia ignobilis Haliday (1836) species with a large amount of pollen from Schinus terebinthifolius Raddi agglomerated in regions of their exoskeleton. This fact confirmed the importance of those species as pollen transporters and as potential pollinators. Given the importance of social wasps, their conservation becomes significant to maintain the diversity of natural environments (SOMAVILLA; KÖHLER, 2012).

Besides the importance of pollination, social wasps contribute to natural biological control both in urban environments and in agroecosystems due to their habit of preying on other insects (CARPENTER; MARQUES, 2001; PREZOTO et al. , 2007; ROCHA, 2011). Among insects predated by wasps, 90\% correspond to lepidopteran caterpillars (PREZOTO et al. , 2007; RESENDE et al., 2016), 
which are considered important pests of several crops (GALLO et al., 2002). This preference for such prey was observed in several studies when analyzing foraged resources, for example, by Polistes versicolor Olivier (1791) (PREZOTO; CLEMENTE, 2010), Polybia occidentalis Olivier (1791), and Polybia paulista Von Ihering (1896) (HERDINA et al., 2016).

Even with all the importance of ecosystem services offered by social wasps, there is still little research on them in urban environments (ALVARENGA et al., 2010; JACQUES et al., 2012, 2015; OLIVEIRA; SOUZA; PIRES, 2017), even in the southeast region, which is the most studied in Brazil (SOUZA; VALE; BARBOSA, 2016). In this way, more studies are needed to better understand this process of association of social wasps with the urban environment, as well as for a better relationship between men and insects (LIMA; LIMA; PREZOTO, 2000; OLIVEIRA et al., 2015; FORTES et al., 2017). Therefore, the objective of this work was to inventory the species of social wasps and verify the number and fluctuation of colonies and preferential substrates used for nesting in the premises of the Federal Institute of Education, Science and Technology of Southern Minas Gerais (IFSULDEMINAS), Machado Campus.

\section{Materials and methods}

The study was conducted at IFSULDEMINAS - Campus Machado, Machado/MG. The municipality has typical vegetation of the seasonal semideciduous forest, Atlantic Forest biome (IBGE, 2012). It is characterized by both the climate of the Cwa type, humid subtropical with dry winter and hot summer (KÖPPEN, 1948) and the average annual temperature and rainfall of $21.2^{\circ} \mathrm{C}$ and 1,824 $\mathrm{mm}$, respectively (MOURA et al., 2007). For the inventory of the social wasps, we conducted monthly collections in November 2015 and in January, March, and June 2016, totalizing four collections, with a total sampling effort of 96 hours. The active collection method was used to carry out the inventory, defining a route that was repeated monthly.

We examined, in each collection, the constructed areas in the Campus, such as buildings, light posts and garden plants, observing the presence of social wasps and accounting for all colonies along this route. The wasps found in colonies or mid-flight were collected with an entomological net and stored in containers with $70 \%$ alcohol. The colonies observed were photographed with A NIKON D3100 digital camera.

The specimens collected were pinned for identification, and are deposited in the collection of the entomology laboratory of the institution. The identification was made through entomological keys (RICHARDS, 1978; CARPENTER; MARQUES, 2001) and from the comparison with the biological collection of social wasps (CBVS) of IFSULDEMINAS - Inconfidentes Campus. The identification of the species was confirmed by Dr. Marcos Magalhães de Souza, from the same institution, and some specimens of the Mischocyttarus de Saussure (1853) were sent to Dr. Orlando Tobias Silveira from the Paraense Emílio Goeldi Museum in Belém - Pará.

The types of substrates used by the social wasps were grouped according to Lima, Lima, and Prezoto (2000) in the following categories: construction (walls, cement structures, and tiles); metal structures (air conditioning, gutters, construction iron, nails, screws, and lamp support); synthetic materials (plastics, rubbers, glasses); wood (masonry structures), and vegetation (all plants where nests were found). In addition to the substrate, the height of the colonies in relation to the soil was grouped into three categories: low (up to two meters), medium (from two to five meters) and high (more than five meters). The collected data were tabulated in spreadsheets (Calc - LibreOffice) for evaluation of the species richness, abundance, and fluctuation of the number of colonies over the months studied. 


\section{Results and discussion}

In Machado Campus from November 2015 to June 2016, a total richness of 20 species of social wasps distributed in seven genera was registered. This richness represents $11.76 \%$ of the total species registered in the Atlantic Forest, an area considered an important refuge for the conservation of these insects in Brazil (SOUZA et al., 2020). The genus Polybia Lepeletier (1836) showed greater species richness (seven), followed by Mischocyttarus de Saussure (1853) with five, Polistes Latreille (1802) with three, Agelaia Lepeletier (1836) with two, and Apoica Lepeletier (1836), Synoeca de Saussure (1852), and Brachygastra Perty (1833) with one species each. Similar results in anthropogenic environments were found by Oliveira, Souza, and Pires (2017), and Jacques et al. (2012), who registered a richness of 16 species distributed in 6 genera and 20 species in 9 genera, respectively.

Among the inventoried species, Agelaia vicina de Saussure (1854), Brachygastra lecheguana Latreille (1824), Polybia sericea Olivier (1791), and Polybia ignobilis Haliday (1836) were collected in mid-flight, but their colonies were not located. The presence of $P$. ignobilis flying over garbage containers was remarkable, while $A$. vicina, $B$. lecheguana, and $P$. sericea were found near the vegetation. Overall, the nest of these species are not found in anthropogenic areas (JACQUES et al., 2015; SOUZA, 2010).

We registered colonies of 16 species and, of the total colonies observed, $80.90 \%$ belong to the genus Mischocyttarus, of which $94.15 \%$ refer to the species $M$. cassununga (TABLE 1 ). The high abundance of this species may be related to the small size of its colonies and their low aggressiveness (CASTRO, 2010; CASTRO et al. 2014), thus not representing a threat to human eyes, which decreases the risk of anthropogenic depredation.

Table 1 - Number of colonies of social wasp species (Hymenoptera Vespidae) found in IFSULDEMINAS Machado Campus from November 2015 to June 2016. Machado-MG.

\begin{tabular}{lcccccc}
\hline \multirow{2}{*}{ Species } & \multicolumn{7}{c}{ Number of colonies } \\
\cline { 2 - 7 } & Nov & Jan & Mar & Jun & Total & Abundance (\%) \\
\hline Mischocyttarus cassununga R. von Ihering (1903) & 401 & 793 & 735 & 422 & 2.351 & 76.21 \\
Polistes * & 12 & 15 & 81 & 76 & 184 & 5.96 \\
Polistes versicolor Olivier (1791) & 19 & 54 & 19 & 61 & 153 & 4.96 \\
Polistes simillimus Zikán (1951) & 8 & 33 & 36 & 7 & 84 & 2.72 \\
Polistes ferreri Saussure (1853) & 11 & 19 & 20 & 7 & 57 & 1.85 \\
Mischocyttarus rotundicollis Cameron (1912) & 7 & 13 & 26 & 4 & 50 & 1.62 \\
Mischocyttarus * & 0 & 14 & 23 & 8 & 45 & 1.46 \\
Mischocyttarus drewseni de Saussure (1954) & 6 & 4 & 17 & 11 & 38 & 1.23 \\
Polybia * & 9 & 9 & 11 & 4 & 32 & 1.04 \\
Polybia platycephala slyventris Richards (1978) & 5 & 8 & 8 & 8 & 29 & 0.94 \\
Polybia scutellaris White (1841) & 2 & 2 & 9 & 6 & 19 & 0.62 \\
Polybia fastidiosuscula Saussure (1854) & 4 & 6 & 5 & 0 & 15 & 0.49 \\
Mischocyttarus paraguayensis Zikán (1935) & 1 & 3 & 7 & 1 & 12 & 0.39 \\
Polybia paulista Von Ihering (1896) & 1 & 3 & 1 & 2 & 7 & 0.23 \\
Synoeca cyanea Fabricius (1775) & 0 & 0 & 0 & 5 & 4 & 0.13 \\
\hline
\end{tabular}


Table 1 - Continuation.

\begin{tabular}{lcccccc}
\hline \multirow{2}{*}{ Species } & \multicolumn{5}{c}{ Number of colonies } \\
\cline { 2 - 7 } & Nov & Jan & Mar & Jun & Total & Abundance (\%) \\
\hline Agelaia multipicta multipicta Haliday (1836) & 0 & 0 & 0 & 1 & 1 & 0.03 \\
Apoica gelida Van der Vecht (1972) & 0 & 0 & 0 & 1 & 1 & 0.03 \\
Mischocyttarus parallellogrammus Zikán (1935) & 1 & 0 & 0 & 0 & 1 & 0.03 \\
Polybia bifasciata Saussure (1854) & 0 & 0 & 0 & 1 & 1 & 0.03 \\
\hline Total & 486 & 976 & 998 & 625 & 3.085 & \\
\hline
\end{tabular}

* It was not possible to collect individuals from these colonies, as they were in a place of difficult access. However, considering the pattern of their architecture, they could be identified at the genus level.

Source: Elaborated by the authors (2020).

The second most representative genus in the number of colonies was Polystes (15.49\%) (TABLE 1). According to Prezoto et al. (2007), wasps of this genus feed on insects such as defoliating caterpillars and aphids, commonly found in gardens and crops, typical environments on Machado Campus that may be providing the abundance of colonies of this species.

The significant number of colonies in anthropogenic areas demonstrates that these sites have favorable conditions for the establishment of social wasps (FERREIRA; SINZATO, 2007). In turn, Machado Campus has a diversity of environments, such as constructions, gardens, agricultural production areas, and forest fragments. Alvarenga et al. (2010), Bueno, Souza, and Clemente (2019), and Jacques et al. $(2012,2015)$ described that environmental heterogeneity, as well as the presence of green areas, are fundamental to the occurrence and abundance of social wasps.

In neotropical regions, where climatic seasons are not well defined, the foundation of new colonies is asynchronous, so it can occur at any time of the year (ROCHA, 2011). During the four months of collection, a monthly average of 771.25 social wasp colonies was observed. As for the genera Mischocyttarus, Polystes and Polybia, there was an increased number of colonies from November to March, decreasing in June (TABLE 1). A greater abundance of social wasps in warmer and rainier periods was also observed by Alvarenga (2012) and Souza et al. (2012). This happens because the seasonality of climatic factors influences wasp foraging activities (PREZOTO et al., 2007), and the rainy season is more favorable because there is greater availability of food resources (CASTRO et al., 2014).

In addition to environmental factors, anthropic depredation directly influences the reduction in the number of larger colonies, such as the genus Polybia, because the size of the colony is related to the danger level of the species (LIMA; LIMA; PREZOTO, 2000), a fact also observed in this study (FIGURE $1 \mathrm{j}-\mathrm{I}$ ). Rocha (2011) found that $60 \%$ of the abandonment of colonies of the Polybia platycephala slyventris Richards (1978) species occurred due to anthropogenic action, especially in the period of intensification of civil works.

The chosen substrate for nesting also interferes with colony success (CASTRO et al., 2014; TORRES et al. , 2014). In Machado Campus, the independent foundation genera, Mischocyttarus and Polistes, which presented the greatest abundance of colonies, had a preference for nesting on artificial substrates (constructions, metal structures, wood, and synthetic material) to the detriment of vegetation substrate (TABLE 2, FIGURE 2a-d, f-j, I, FIGURE 3), which was also was found by Lima, Lima, and Prezoto (2000). These substrates offer more protection against climatic variations when compared to herbaceous plants, and those that have small and deciduous leaves (CASTRO et al., 2014). 
Besides protection against weather conditions, nesting in human housing reduces interspecific competition and predation (TORRES et al., 2014).

Figure 1 - Wasp colonies of the genus Polybia and substrates used, found in IFSULDEMINAS - Machado Campus from November 2015 to June 2016.
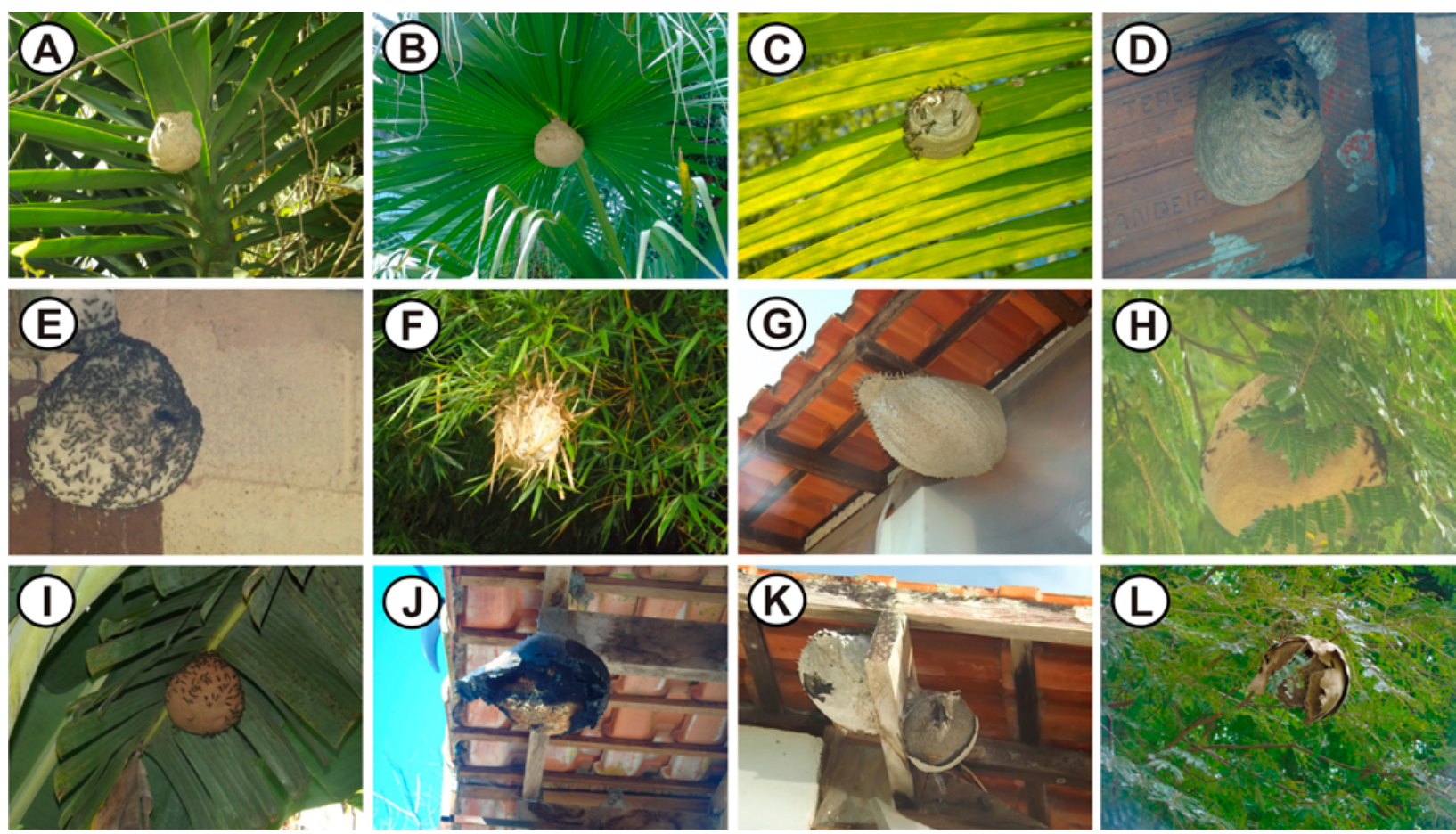

Legend. A-C: Polybia platycephala slyventris Richards (1978), D-E: Polybia paulista Von Ihering (1896), F: Polybia sp., G: Polybia scutellaris White (1841), H-I: Polybia fastidiosuscula Saussure (1854), $\mathrm{J}-\mathrm{L}$ : Depredation of $P$. scutellaris $(\mathrm{J}-\mathrm{K})$ and $P$. fastidiosuscula $(\mathrm{L})$ colonies.

Source: Elaborated by the authors (2020).

Table 2 - Categories of substrates used for nesting by the social wasp genera found in IFSULDEMINAS Machado Campus, from November 2015 to June 2016. Machado-MG.

\begin{tabular}{lccccc}
\hline \multicolumn{1}{c}{ Genera } & Construction & Metal structures & $\begin{array}{c}\text { Synthetic } \\
\text { materials }\end{array}$ & Wood & Vegetation \\
\hline Agelaia & 0.00 & 0.00 & 0.00 & 0.00 & 100.00 \\
Apoica & 100.00 & 0.00 & 0.00 & 0.00 & 0.00 \\
Mischocyttarus & 46.57 & 22.01 & 9.53 & 20.69 & 1.19 \\
Polistes & 25.00 & 16.10 & 5.08 & 53.39 & 0.42 \\
Polybia & 22.55 & 26.47 & 0.98 & 20.59 & 29.41 \\
Synoeca & 0.00 & 0.00 & 0.00 & 0.00 & 100.00 \\
\hline
\end{tabular}

Source: Elaborated by the authors (2020). 
Figure 2 - Wasps colonies of the genus Mischocyttarus and substrates used, found in IFSULDEMINAS Machado Campus from November 2015 to June 2016.
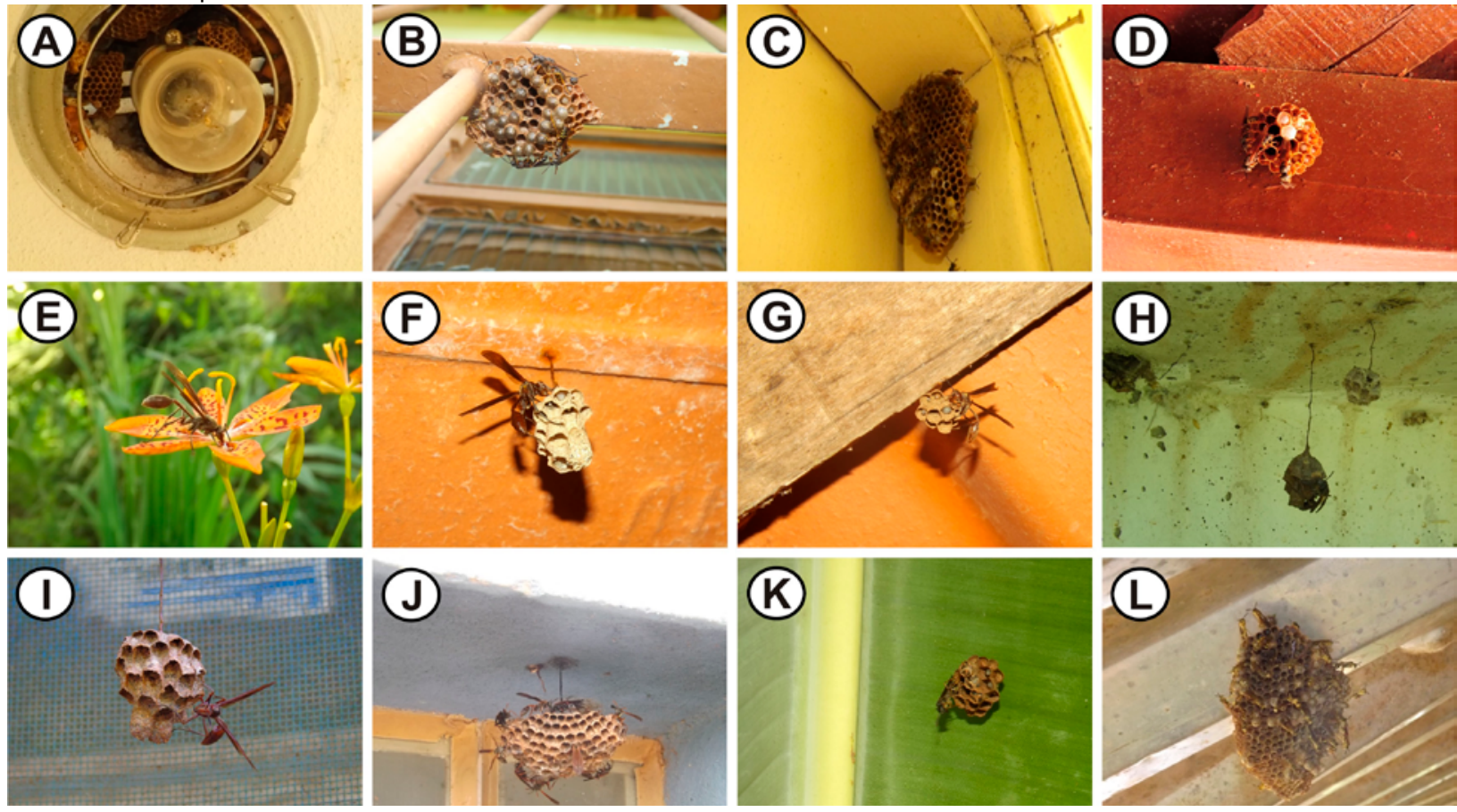

Legend. A-D: Mischocyttarus cassununga R. von Ihering (1903), E-G: Mischocyttarus drewseni de Saussure (1054), H-J: Mischocyttarus rotundicollis Cameron (1912), K: Mischocyttarus parallellogrammus Zikán (1935), L: Mischocyttarus paraguayensis Zikán (1935).

Source: Elaborated by the authors (2020).

Figure 3 - Wasps colonies of the genus Polistes and substrates used, found in IFSULDEMINAS - Machado Campus from November 2015 to June 2016.
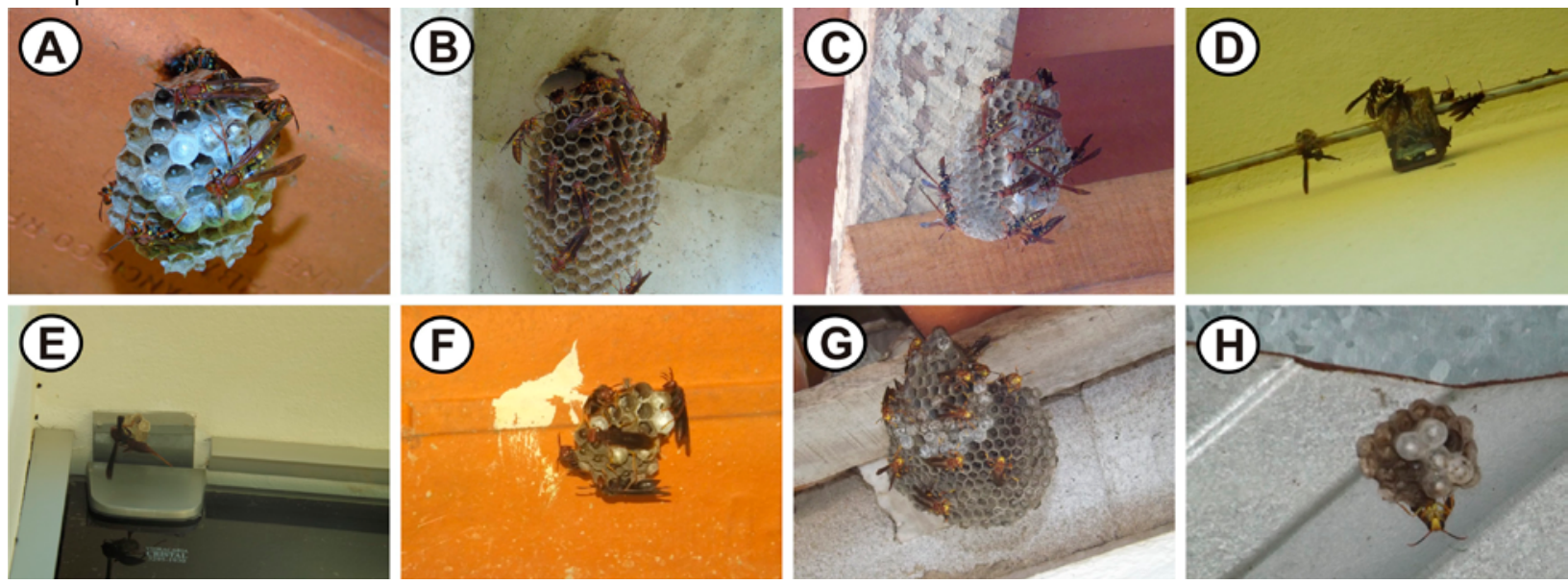

Legend. A-C: Polistes versicolor Olivier (1791), D-F: Polistes ferreri Saussure (1853), G-H: Polistes simillimus Zikán (1951).

Source: Elaborated by the authors (2020).

Among the Polistes species, we observed that Polistes ferreri Saussure (1853) preferred metal structures (77\%), and most of its colonies were found near the air conditioners installed in the buildings surveyed (FIGURE 3d, e), where the wasps were spotted foraging probably by the water released by the 
equipment. In dry and cold seasons, this resource is a determining factor for the survival of individuals due to the decrease in food resources (ELPINO-CAMPOS; DEL-CLARO; PREZOTO, 2007).

In addition to the substrate, the height of the colonies is crucial to their success, especially for those independent foundation species that have few individuals per colony (PREZOTO; CLEMENTE, 2010). In the present work all species of the genus Polistes and the Mischocyttarus cassununga R. von Ihering, (1903) species built their colonies between two and five meters from the ground (79 \% and $70 \%$, respectively). These species have a preference for nesting in human housing, and the height of colonies is equivalent to that of windows and roofs, making them more discreet for human perception, which is possibly a strategy against depredation (ALVARENGA et al., 2010; FERREIRA; SINZATO, 2007; ALVARENGA, 2012; CASTRO et al. , 2014) (FIGURE 2 a-d,f-h,j,l). Unlike M. cassununga, colonies of the Mischocyttarus drewseni de Saussure (1954) and Mischocyttarus rotundicollis Cameron (1912) species were found preferentially in the low height category (54\% and $59 \%$, respectively), but were generally in more protected locations and with the lower flow of people.

Similarly to Polistes and $M$. cassununga, the genus Polybia presented a preference for nesting in the average height category (70\%), but the preferred substrate for nesting was in plants (TABLE 2 and FIGURE 1a-c,f,h,i,l). Among the species, P. platycephala slyventris was found mainly in the adaxial part of the palm tree Livistona chinensis (Jack.) R. Br. ex. Mart (FIGURE 1b). This palm tree is abundant in urban gardens and it has considerable height and broad leaves, which provides shelter and protection to social wasps against adverse weather conditions (ALVARENGA et al., 2010; ALVARENGA, 2012).

Besides $L$. chinensis, species of the genus Polybia have also been found in other plants. Polybia bifasciata Saussure (1854) was found only once in Coffea arabica L.; P. platycephalla slyventris was found in Yucca elephantipes Regel (FIGURE 1a) and in Dypsis lutescens (H.Wendl.) Beent. \& J.Dransf. (FIGURE 1c); Polybia sp. was found in Bambusa sp. (FIGURE 1f) and in Magnolia champaca (L.) Baill. ex Pierre; Polybia fastidiosuscula Saussure (1854) was found in Caesalpinia pluviosa DC. (FIGURE 1h); and P. platycephalla slyventris and $P$. fastidiosuscula were found in Musa sp. (FIGURE 1I). Rodríguez et al. (2012) also recorded P. platycephlla slyventris in Musa sp. leaf and cited that this species can contribute to the biological control of pest caterpillars of this plant.

The genus Synoeca presented only one species, Synoeca cyanea Fabricius, (1775) and all colonies were registered only in June (TABLE 1). According to Elisei et al. (2005), this species prefers foraging throughout the day under high temperatures and low humidity, typical conditions of drier seasons. Padua et al. (2017) reported that in those seasons, people tend to view colonies of social wasps more easily due to the deciduousness of the trees.

Colonies of $S$. cyanea were registered only in the vegetation substrate, in the shrub Y. elephantipes (FIGURE 4e, f) and trees of the family Leguminosae as Anadenanthera sp. (FIGURE 4d) and $C$. pluviosa. Regarding height, in the bushes, the colony was found in the low category, and upon the trees in the high category. Oliveira, Souza, and Pires (2017) also observed this species with nesting restricted to vegetation and explained that it occurs due to the type of colony. Also, nesting of $S$. cyanea in Anadenanthera sp. may facilitate thermal regulation of the colony during winter, since they are deciduous plants and allow more exposure to sunlight (SOUZA, 2010). 
Figure 4 - Wasps colonies of the genera Agelaia, Apoica and Synoeca and substrates used, found in IFSULDEMINAS - Machado Campus from November 2015 to June 2016.
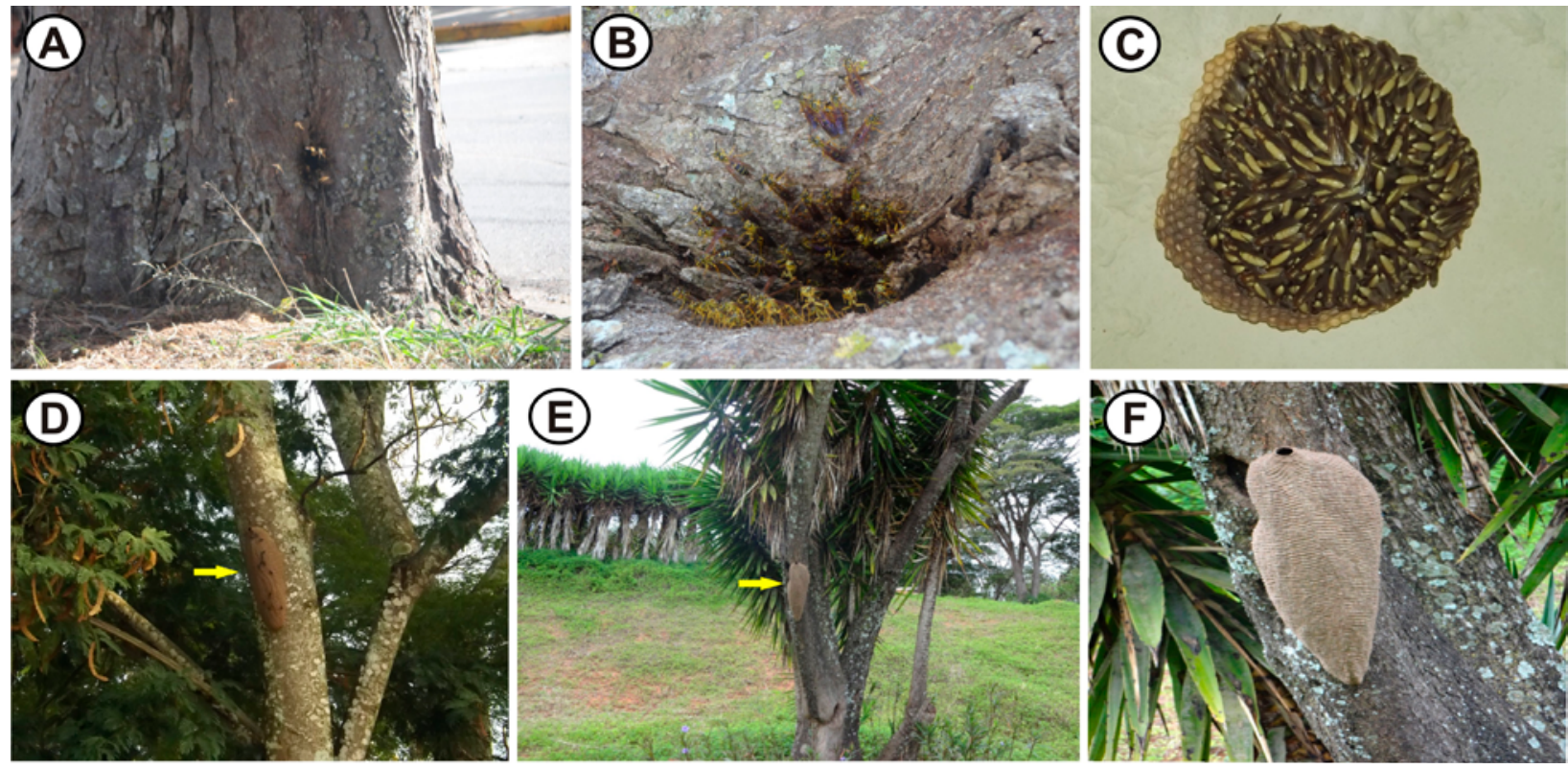

Legend. A-B: Agelaia multipicta multipicta Haliday (1836), C: Apoica gelida Van der Vecht (1972), D-F: Synoeca cyanea Fabricius (1775).

Source: Elaborated by the authors (2020).

Like Synoeca, the genus Apoica presented only one species, Apoica gelida Van der Vecht (1972), being found only one colony in the substrate construction at an average height category (FIGURE 4c). Species of this genus are characterized by nocturnal habits (CARPENTER; MARQUES, 2001), therefore it is more difficult to collect them during the day (JACQUES et al., 2015).

Two species of the genus Agelaia, A. vicina and Agelaia multipicta multipicta Haliday (1836) were registered. Species of this genus are characterized by nesting in soil cavities and tree trunks (SOMAVILLA; OLIVEIRA; SILVEIRA, 2012). In this study, the A. multipicta multipicta colony was found at the base of the $C$. pluviosa trunk (FIGURE $4 a, b$ ). Although the $A$. vicina colony was not found, it was the most abundant among the species captured in attractive traps in the vegetable garden of Machado Campus (FORTES; FORTES; FERNANDES, 2018).

The richness and abundance of social wasp colonies found in IFSULDEMINAS - Machado Campus show that these insects are part of the daily lives of the people. However, the occurrence of many species in anthropogenic environments is threatened due to human depredation of colonies, mainly by the indiscriminate use of insecticides (SILVA FILHO; CASINO, 2004). Thus, environmental education is essential to inform about the ecosystem's importance of social wasps and to promote their conservation (PÁDUA et al., 2017; OLIVEIRA et al., 2015; SOUZA, 2010).

\section{Conclusion}

IFSULDEMINAS - Machado Campus has a diversity of environments that contributes to the settling of colonies of social wasps. Over the months studied, we observed a decrease in the number of colonies from the rainy to the dry season. The genus Polybia had more richness of species, but the genus Mischocyttarus, especially the species Mischocyttarus cassununga, had more abundance 
of colonies in all months evaluated, which owes to their preference for human-housing nesting and their low aggressiveness. Given the synthropy of social wasps, it is essential that the community, which has direct contact with the insects, knows their importance and preserve them. Therefore, environmental education actions are necessary to both disseminate such information and teach the correct management of the colonies.

\section{Acknowledgments}

To IFSULDEMINAS - Machado Campus, for granting the scholarship, and Prof. Dr. Marcos Magalhães de Souza for his assistance in identifying the species.

\section{Inventário, flutuação das colônias e hábitos de nidificação de vespas sociais no IFSULDEMINAS - Campus Machado}

\section{Resumo}

As vespas sociais oferecem importantes recursos ecossistêmicos como controle biológico e polinização. Muitas espécies são sinantrópicas, no entanto, ainda há poucos estudos sobre esses insetos em ambientes antropizados. Objetivou-se com este trabalho verificar a riqueza, a flutuação das colônias e os substratos preferenciais para nidificação de vespas sociais no IFSULDEMINAS Campus Machado. Foram realizados quatro censos/inventários no período de novembro de 2015 a junho de 2016; para a coleta de vespas, utilizou-se do método de coleta ativa com rede entomológica. Os espécimes encontrados foram montados, identificados e depositados na coleção do Laboratório de Entomologia da instituição. No total foram registradas 20 espécies de vespas sociais, os gêneros Polybia, Polistes e Mischocyttarus apresentaram maior riqueza de espécies. Houve um aumento no número de colônias do mês de novembro a março e um decréscimo em junho. Mischocyttarus cassununga R. von Ihering (1903) apresentou maior abundância de colônias em todos os meses avaliados. De modo geral, os gêneros Mischocyttarus e Polistes apresentaram preferência de nidificação pelo substrato construção, enquanto o gênero Polybia apresentou preferência pelo substrato vegetação. O Campus Machado possui uma diversidade de ambientes que contribui para o estabelecimento de colônias de vespas sociais. Logo, é imprescindível a divulgação dessas informações para a comunidade, além de ações de educação ambiental que demonstrem a importância desses insetos para o ecossistema e a necessidade da conservação ambiental para garantia dos seus serviços ecossistêmicos.

Palavras-chave: Entomologia. Hymenoptera Vespidae. Mischocyttarus. Sinantropismo.

\section{References}

ALVARENGA, R. B. Vespas sociais (Hymenoptera, Vespidae) em áreas antrópicas. 2012. 46 p. Dissertação (Mestrado em Comportamento e Biologia Animal) - Universidade Federal de Juiz de Fora, Juiz de Fora, 2012.

AlVARENGA, R. B.; CASTRO, M. M. de; PREZOTO, H. H. S.; PREZOTO, F. Nesting of social wasps (Hymenoptera, Vespidae) in urban gardens in Southeastern Brazil. Sociobiology, 
v. 55, n. 2, p. 445-452, 2010. Available at: https://www.researchgate. net/publication/266853554_ Nesting_of_Social_Wasps_Hymenoptera_Vespidae_in_Urban_Gardens_in_Southeastern_Brazil. Access on: 22 jun. 2020.

BUENO, E. T.; SOUZA, M. M.; CLEMENTE, M. A. The effect of forest fragmentation on Polistinae. Sociobiology, v. 66, n. 3, p. 508-514, 2019. Available at: http://periodicos.uefs.br/index.php/ sociobiology/article/view/4378. Access on: 22 jun. 2020.

CARPENTER, J. M.; MARQUES, O. M. Contribuição ao estudo dos vespídeos do Brasil. Cruz das Almas, Universidade Federal da Bahia. Publicações digitais, v. 2. Universidade Federal da Bahia. 2001. 147 p.

CASTRO, M. M. de. Desenvolvimento pós-embrionário, oofagia e relação entre as interações de dominância e a atividade forrageadora na vespa social Mischocyttarus cassununga (Von Ihering, 1903) (Hymenoptera, Vespidae). 2010. 84p. Dissertação (Mestrado em Comportamento e Biologia Animal) - Universidade Federal de Juiz de Fora, Juiz de Fora, 2010.

CASTRO, M. M. de; AVELAR, D. L. G. de; SOUZA, A. R. de; PREZOTO, F. Nesting substrata, colony success and productivity of the wasp Mischocyttarus cassununga. Revista Brasileira de Entomologia, v. 58, n. 2, p. 168-172, 2014. Available at: http://www.scielo.br/pdf/rbent/v58n2/a09v58n2.pdf. Access on: 22 jun. 2020.

CASTRO, M. M. de; GUIMARÃES, D. L.; PREZOTO, F. Influence of environmental factors on the foraging activity of Mischocyttarus cassununga (Hymenoptera, Vespidae). Sociobiology, v. 58, n. 1, p. 1-10, 2011. Available at: https://www.researchgate.net/publication/266853624_Influence_ of_Environmental_Factors_on_the_Foraging_Activity_of_Mischocyttarus_cassununga_Hymenoptera_ Vespidae. Access on: 22 jun. 2020.

CLEMENTE, M. A.; VIEIRA, K. M.; CAMPOS, N. R.; DEL-CLARO, K.; PREZOTO, F. Social wasp guild (Hymenoptera: Vespidae) visiting flowers in two of the phytophysiognomic formations: Riparian Forest and campos rupestres. Sociobiology, v. 64, n. 2, p. 217, 2017. Available at: http://periodicos.uefs. br/index.php/sociobiology/\%20article/view/136. Access on: 22 jun. 2020.

ELPINO-CAMPOS, Á.; DEL-CLARO, K.; PREZOTO, F. Diversity of social wasps (Hymenoptera: Vespidae) in cerrado fragments of Uberlândia, Minas Gerais state, Brazil. Ecology, Behavior and Bionomics, v. 36, n. 5, p. 685-692, 2007. Available at: http://www.scielo.br/scielo.php?script=sci_ arttext\&pid=S1519-566X2007000500008. Access on: 22 jun. 2020.

ELISEI, T.; RIBEIRO JUNIOR, C; GUIMARÃES, D. L.; PREZOTO, F. Foraging activity and nesting of swarmfounding wasp Synoeca cyanea (Hymenoptera: Vespidae, Epiponini. Sociobiology, v. 46, n. 2, p. 317327, 2005. Available at: https://www.researchgate.net/profile/Thiago_Elisei/publication/236146814_ Foraging_Activity_and_Nesting_of_SwarmFounding_Wasp_Synoeca_cyanea_Hymenoptera_Vespidae_ Polistinae/links/Odeec5165c1ef42558000000.pdf. Access on: 22 jun. 2020.

ELISEI, T.; VAZ, J.; RIBEIRO JUNIOR, C.; FERNANDES JUNIOR, A. J.; PREZOTO, F. Uso da vespa social Polistes versicolor no controle de desfolhadores de eucalipto. Pesquisa Agropecuária Brasileira, 
v. 45, n. 9, p. 958-964, 2010. Available at: http://www.scielo.br/pdf/pab/v45n9/a04v45n9.pdf. Access on: 22 jun. 2020.

FORTES, A. R.; FORTES, E. A.; FERNANDES, L. G. Avaliação de diferentes atrativos na coleta de vespas (Hymenoptera: Vespidae) em área de produção de hortaliças. In: Cadernos de Agroecologia Anais... VI CLAA, X CBA e V SEMDF - V, v. 13, n. 1, 2018.

FORTES, E. A.; FORTES, A. R.; ALMEIDA, L. C. de; FERNANDES, L. G. Riqueza de vespas sociais (Hymenoptera Vespidae) no IFSULDEMINAS - Campus Machado. In: $9^{\circ}$ JORNADA CIENTÍFICA E TECNOLÓGICA DO IFSULDEMINAS, E 60 SIMPÓSIO DE PÓS-GRADUAÇÃO, 6 a 8 novembro de 2017, Machado, MG. Anais... Machado, v. 9, 2017 Available at: https://jornada.ifsuldeminas.edu. br/index.php/jcpcs/jcpcs/paper/viewFile/943/700. Access on: 22 jun. 2020.

FERREIRA, E. L.; SINZATO, D. M. S. Ocorrência e sítio de nidificação de vespas sociais Polistes sp. (Hymenoptera, Vespidae) no Parque Aquático Águas Quentes, Barra do Piraí/RJ. In: VIII CONGRESSO DE ECOLOGIA DO BRASIL, 2007, Caxambu. Actas... Caxambu: [s.n.], 2007, p. 1-2. Available at: http://www.seb-ecologia.org.br/revistas/indexar/anais/viiiceb/pdf/2072.pdf. Access on: 22 jun. 2020.

GALLO, D.; NAKANO, O.; SILVEIRA-NETO, S.; CARVALHO, R. P. L.; BATISTA, G. C.; BERTI-FILHO, E.; PARRA, J. R. P.; ZUCCHI, R. A.; ALVES, S. B.; VENDRAMIM, J. D.; MARCHINI, L. C.; LOPES, J. R. S.; OMOTO, C. Manual de Entomologia agrícola. Piracicaba: FEALQ, 2002. 920 p.

HERDINA, A. S.; BITTENCOURT, G.; DI MARE, R.; BARBOSA, B. C. Polybia (Myrapetra) scutellaris (Hymenoptera: Vespidae) foraging on flies at carcasses of Rattus norvegicus (Rodentia: Muridae). Sociobiology, v. 63, n. 1, p. 728-730, 2016. Available at: http://periodicos.uefs.br/index.php/ sociobiology/article/view/937. Access on: 22 jun. 2020.

IBGE - Instituto Brasileiro de Geografia e Estatística. Manual técnico da vegetação brasileira: sistema fitogeográfico, inventário das formações florestais e campestres, técnicas e manejo de coleções botânicas, procedimentos para mapeamentos. Rio de janeiro: IBGE- Diretoria de Geociências (Manuais Técnicos de Geociências, 1), 2012. 271 p.

JACQUES, G. C; CASTRO, A. A. de; SOUZA, G. K.; SILVA-FILHO, R.; SOUZA, M. M. de; ZANUNCIO, J. C. Diversity of social wasps in the Campus of the "Universidade Federal de Viçosa" in Viçosa, Minas Gerais state, Brazil. Sociobiology, v. 59, n. 2, p. 1-10, 2012. Available at: http://periodicos.uefs.br/ ojs/index.php/sociobiology/article/view/566. Access on: 22 jun. 2020.

JACQUES, G. C.; SOUZA, M. M.; COELHO, H. J.; VICENTE, L. O.; SILVEIRA, L. C. P. Diversity of social wasps (Hymenoptera: Vespidae: Polistinae) in an agricultural environment in Bambuí, Minas Gerais, Brazil. Sociobiology, v. 62, n. 3, p. 439-445, 2015. Available at: http://periodicos.uefs.br/ index.php/sociobiology/article/view/738/0. Access on: 22 jun. 2020.

KÖPPEN, W. Climatología: con un estudio de los climas de la tierra. Ed. Fondo de Cultura Económica, Ciudad de México. 1948. 478 p. 
LIMA, M. A. P.; LIMA, J. R.; PREZOTO, F. Levantamento dos gêneros, flutuação das colônias e hábitos de nidificação de vespas sociais (Hymenoptera, Vespidae) no Campus da UFJF, Juiz de Fora, MG. Revista Brasileira de Zoociências, v. 2, n. 1, p. 57-67, 2000. Available at: https://periodicos.ufjf.br/ index.php/zoociencias/article/view/24289. Access on: 22 jun. 2020.

MOURA, L. C.; MARQUES, A. F. S. M; HADAD, R. M.; ANDRADE, H.; ALVES, H. M. R. A Aptidão Agrícola das Terras do município de Machado - MG e a Cafeicultura. Caderno de Geografia, v. 17, n. 28, p. 141-162, 2007.

OLIVEIRA, T. C. T.; SOUZA, M. M.; PIRES, E. P. Nesting habits of Social wasps (Hymenoptera: Vespidae) in forest fragments associated with anthropic areas in southeastern Brazil. Sociobiology, v. 64, n. 1, p. 101-104, 2017. Available at: http://periodicos.uefs.br/index.php/sociobiology/article/ view/1073. Access on: 22 jun. 2020.

OLIVEIRA, T. C. T.; SOUZA, M. M.; SOUZA, A. F. L.; PASSARI, G. J.; FERREIRA, J. S.; SILVA, R. A. Nidificação de vespas sociais (Hymenoptera, Vespidae) em fragmentos urbanos do Sul de Minas Gerais. In: $7^{\circ}$ JORNADA CIENTÍFICA E TECNOLÓGICA DO IFSULDEMINAS, E $4^{\circ}$ SIMPÓSIO DE PÓS-GRADUAÇÃO, Poços de Caldas, Minas Gerais, 12 de novembro de 2015. Anais... Poços de Caldas, v. 7, 2015. 7p. Available at: https://jornada.ifsuldeminas.edu.br/index.php/jcpcs/jcpcs/paper/ viewFile/943/700. Access on: 22 jun. 2020.

PÁDUA, D. C. de; SOUZA, M. de; BRUNISMANN, Â.; COELHO, E.; PIRES, E. Conhecimento popular sobre vespas sociais (Hymenoptera, Vespidae) nas comunidades do Entorno do Refúgio da Vida Silvestre do Rio Pandeiros, Norte do Estado De Minas Gerais. Ethnoscientia, v. 2, n. 1, p. 1-11, 2017. Available at: http://www.ethnoscientia.com/index.php/revista/article/view/83. Access on: 22 jun. 2020.

PREZOTO, F. A importância das vespas como agentes no controle biológico de pragas. Biotecnologia Ciência \& Desenvolvimento, v. 2, n. 9, p. 24-26, 1999. Available at: https://www.researchgate. net/publication/267445178_A_importancia_das_vespas_como_agentes_no_controle_biologico_de_ pragas. Access on: 22 jun. 2020.

PREZOTO, F.; CLEMENTE, M. A. Vespas sociais do Parque Estadual do Ibitipoca, Minas Gerais, Brasil. MG BIOTA, v. 3, n. 4, p. 22-32, 2010.

PREZOTO, F.; RIBEIRO-JÚNIOR, C.; OLIVEIRA-CORTES, S. A.; ELISEI, T. Manejo de vespas e marimbondos em ambiente urbano. In: PINTO, A. S., ROSSI, M. M.; SALMERON, E. (orgs.). Manejo de Pragas Urbanas. Piracicaba, Editora CP2, 2007. 192 p.

RESENDE, L. de O.; PREZOTO, F.; BARBOSA , B. C.; GONÇALVES, E. L. Sustentabilidade: Tópicos da Zona da Mata Mineira. Juiz de Fora: Edição dos autores, [s.I: s.n.], 2016, p. 19-30.

RICHARDS, O. W. The social wasps of the America, excluding the Vespinae. London, British Museum (Natural History), 1978. 580 p. 
RICHTER, M. R. Social wasp (Hymenoptera: Vespidae) foraging behavior. Annual Review of Entomology, v. 45, p. 121-150, 2000. Available at: https://www.annualreviews.org/doi/abs/10.1146/annurev. ento.45.1.121. Access on: 22 jun. 2020.

ROCHA, M. de P. Biologia e ecologia comportamental da vespa social Polybia platycephala (Richards, 1978) (Hymenoptera, Vespidae, Epiponini). 2011. 76 p. Dissertação (Mestrado Comportamento e biologia animal) - Universidade Federal de Juiz de Fora, Juiz de Fora, 2011.

RODRÍGUEZ, F.; BARROS, L.; CAROLINE, P.; SOUZA, M. M.; SERRÃO, J. E.; ZANUNCIO, J. C. Nidification of Polybia platycephala (Hymenoptera: Vespidae) on plants of Musa spp. in Minas Gerais state, Brazil. Sociobiology, v. 59, n. 2, p. 457-461, 2012. Available at: http://periodicos.uefs.br/ index.php/sociobiology/article/view/609. Access on: 22 jun. 2020.

SILVA-FILHO, R.; CASSINO, P. C. R. Marimbondos. Informativo dos entomologistas do Brasil, n. 2, p. $11-13,2004$.

SOMAVILLA, A.; KÖHLER, A. Preferência floral de vespas (Hymenoptera, Vespidae) no Rio Grande do Sul, Brasil. EntomoBrasilis, v. 5, n. 1, p. 21-28, 2012. Available at: https://www.entomobrasilis. org/index.php/ebras/article/view/152. Access on: 22 jun. 2020.

SOMAVILLA, A.; OLIVEIRA, M. L. de; SILVEIRA, O. T. Guia de identificação dos ninhos de vespas sociais (Hymenoptera, Vespidae, Polistinae) na Reserva Ducke, Manaus, Amazonas, Brasil. Revista Brasileira de Entomologia, v. 56, n. 4, p. 405- 414, 2012. Available at: https://www.scielo.br/ scielo.php?pid=S0085-56262012000400003\&script=sci_arttext. Access on: 22 jun. 2020.

SOUZA, M. M. de. Vespas sociais ( Hymenoptera : Vespidae ) indicadoras do grau de conservação de florestas ripárias. 2010. 65 p. Dissertação (Mestrado em Entomologia) - Universidade Federal de Lavras, Lavras, 2010.

SOUZA, M. M. de; FERREIRO, J. S.; ALBUQUERQUE, C. H. B. de. Coleção taxonômica de vespas sociais (Hymenoptera, Vespidae) do Instituto Federal de Educação, Ciência e Tecnologia do Sul de MG, Campus Inconfidentes. MG BIOTA, v. 8, n. 3, p. 16-30, 2015.

SOUZA, M. M.; PIRES, E. P.; FERREIRA, M.; LADEIRA, T. E.; PEREIRA, M. ELPINO-CAMPOS, A.; ZANUNCIO, J. C. Biodiversidade de vespas sociais (Hymenoptera: Vespidae) do Parque Estadual do Rio Doce, Minas Gerais, Brasil. MG BIOTA, v. 5, n. 1, p. 4-19, 2012. Available at: https://www.researchgate. net/publication/267776727_Biodiversidade_de_vespas_sociais_Hymenoptera_Vespidae_do_Parque_ Estadual_do_Rio_Doce_Minas_Gerais_Brasil. Access on: 22 jun. 2020.

SOUZA, M. M.; TEOFILO-GUEdES, G. S.; MILANI, L. R.; SOUZA, A. S. B. de; Gomes, P. P. Social Wasps (Vespidae: Polistinae) from the Brazilian Atlantic Forest. Sociobiology, v. 67, n. 1, p. 1-12, 2020. Available at: http://periodicos.uefs.br/ojs/index.php/sociobiology/article/view/4597. Access on: 22 jun. 2020.

SOUZA, C. A.; VALE, A. C.; BARBOSA, B. C. Vespas Sociais (Vespidae: Polistinae) em fitofisionomias urbanas: um checklist do município de Barra Mansa, Rio de Janeiro, Brasil. EntomoBrasilis, v. 9, 
n. 3, p. 169-174, 2016. Available at: https://www.entomobrasilis.org/index.php/ebras/article/view/ ebrasilis.v9i3.620. Access on: 22 jun. 2020.

SÜHS, R. B. ; SOMAVILLA, A.; KÖHLER, A.; PUTZKE, J. Vespídeos (Hymenoptera, Vespidae) vetores de pólen de Schinus terebinthifolius Raddi (Anacardiaceae), Santa Cruz do Sul, RS, Brasil. Brazilian Journal of Biosciences, v. 7, n. 2, p. 138-143, 2009. Available at: https://www.researchgate. net/publication/288273875_Vespideos_Hymenoptera_Vespidae_vetores_de_polen_de_Schinus_ terebinthifolius_Raddi_Anacardiaceae_Santa_Cruz_do_Sul_RS_Brasil. Access on: 22 jun. 2020.

TORRES, R. F. ; TORRES, V. O.; SÚAREZ, Y. R.; ANTONIALLI, W. F. Effect of the habitat alteration by human activity on colony productivity of the social wasp Polistes versicolor (Olivier) (Hymenoptera: Vespidae). Sociobiology, v. 61, n. 1, p. 100-106, 2014. Available at: http://periodicos.uefs.br/ojs/ index.php/sociobiology/article/view/243. Access on: 22 jun. 2020.

Received: March 7, 2020

Accepted: June 25, 2020 